\title{
Türkiye'de Dış Borçlar Sürdürülebilir mi? ARIMA Modeli
}

\author{
Are External Debts Sustainable in Turkey? ARIMA Model
}

\begin{abstract}
Ersin YENISU (iD) 1
$\ddot{O} z$

Dış borçlar özellikle ikinci dünya savaşından sonra az gelişmiş ve gelişmekte olan ülkelerce kalkınma amacıyla kullanılan bir gelir kaynağı olmuştur. Tasarruf açı̆̆ı dolayısıyla sermaye birikimi yetersiz olan Türkiye gibi ülkeler dış borçları çoğu zaman verimli ve ekonomilerin üretim gücünü arttıracak şekilde kullanamamışlardır. Mali açıklarını kapatmaya çalışan ülkeler için dış borç sarmalı zamanla söz konusu borçların sürdürülemez bir düzeye gelmesine yol açmıştır. Literatüre göre genellikle ekonomik büyüme üzerinde negatif etkileri olan dış borç anapara ve faiz ödemelerinin sürdürülebilirliği ve dış borçların etkin kullanıp kullanılmadığı günümüzde önem taşımaktadır. Nitekim bu çalışmada Türkiye'nin dış borçlarının sürdürülebilir olup olmadığı araştırılmıştır. Çalışmanın temel amacı Türkiye'de dış borç yapısını analiz etmek ve öngörü yöntemiyle dış borçların sürdürülebilir olup olmadığı tespit etmektir. Bunun için 19902016 yıllık verileri kullanılmış olup analiz aracı olarak grafiklerden, tablolardan ve ekonometrik bir yöntem olan ARIMA modelinden yararlanılmıştır. Çalışmada ARIMA modeliyle 2017-2025 yılları "Dış Borç Stoku", "GSYİH" ve "İhracat" değerleri tahmin edilmiştir. Sonuç olarak bu çalışmaya göre Türkiye'de diş borçlar sürdürülebilirdir. Fakat eşik değerde bulunulması nedeniyle dış borç yönetiminde ihtiyatlı olunmasının gerektiği de açıktır. Diğer taraftan dış borç stoku konusu sadece bir ülkenin mevcut mali dengeleri üzerinde değil aynı zamanda gelecek kuşakların üzerine ekonomik bir yük getirmesi açısından da değerlendirilmelidir.
\end{abstract}

Anahtar Kelimeler: Dış borçlar, ekonomik büyüme, ARIMA modeli

Makale Türü: Araştırma

\begin{abstract}
External debts, especially after the Second World War, have become a source of income for the purposes of economic growth in terms of underdeveloped and developing countries. Countries with insufficient savings and insufficient capital accumulation, such as Turkey, generally not able to use external debt as efficient and to increase the production power of the economy. For countries trying to close their fiscal deficits, external debt has led to the unsustainable rise in debt over time. External debt, which is generally negative effects on economic growth according to the literature, is important nowadays when sustainability of principal and interest payments and not efficient of external debt. This study investigates whether Turkey's external debt sustainable. The main objective of the study was to analyze the structure of external debt and to determine whether external debt is sustainable by way of forecasting. For this, 1990-2016 annual data was used and graphs, tables and an econometric method ARIMA model were used as an analysis tool. In the study, the "External Debt Stock", "GDP" and "Export" values for the years 2017-2025 were estimated with ARIMA model. As a result, according to this study in Turkey external debt is sustainable. But it is also clear that external debt management should be cautious because of the threshold level. On the other hand, the external debt issue should be evaluated not only in terms of the current financial balances of an individual country but also in terms of the economic burden of future generations.
\end{abstract}

Keywords: External debts, economic growth, ARIMA model

Paper Type: Research

${ }^{1}$ Ankara Hacı Bayram Veli Üniversitesi, ersinyenisu@gmail.com. 


\section{Giriş}

Dış borçların bir ülkedeki atıl pozisyonda bulunan üretim faktörlerinin harekete geçirilebilmesi için gerekli fon kaynağı olduğu teorisyenlerce ileri sürülmektedir. Nitekim çoğu az gelişmiş ve gelişmekte olan ülkede yatırımları finanse edecek yurtiçi tasarruflar yetersizdir. Bu nedenle sermaye eksikliğinin üretici güçleri harekete geçirmekte temel sorun olduğu söylenebilir. Bununla birlikte birçok ülkede dış borçların üretici güçleri harekete geçirmediği ve mevcut dengelerde oluşan açıkların kapatılmasında kullanıldığı görülmektedir. Genellikle gelişmiş ülkelerden az gelişmiş ve gelişmekte olan ülkelere doğru olan bu borç ilişkisinin ekonomik sebepleri olduğu kadar politik birtakım sebeplerinin de olduğu bir gerçektir. Hatta bu borç ilişkilerinin borç alan ülkelerin sömürülmesine veya ekonomik bağımlılığa yol açabileceği de ihtimal dâhilinde olabilir.

Literatürde daha ziyade borç alan ülkeler açısından dış borçların sürdürülebilirliği ve ekonomik büyümeye katkısının olup olmadığı incelenmiştir. Örneğin Afrika ülkelerinin dış borç yapısını analiz eden Muhanji ve Ojah (2011) çalışmalarında söz konusu ülkelerin dış borçlarının sürdürülebilirlik koşulu olarak daha iyi yönetimi ve etkin döviz kuru stratejisini öne sürmüşlerdir. Aynı konuyu inceleyen Çukurçayır (2014) eşbütünleşme yöntemini kullanmış ve Türkiye'de dış borçların 1980-2010 yılları arasında sürdürülebilir olduğunu bulgulamıştır. Bununla beraber sürdürülebilirlik konusunda farklı çalışmalarda farklı bulguların olduğu görülmektedir. Diğer taraftan dış borç büyüme ilişkisini araştıran Çoban vd. (2016) dış borçların ekonomik büyüme üzerinde negatif etkiye sahip olduğunu bulgulamışlardır. Benzer şekilde birçok çalışmada dış borçların ekonomik büyüme üzerinde olumsuz etkiye sahip olduğunu gösteren kanıtlar vardır.

Bu çalışmanın da amacı Türkiye'de dış borçların görünümünü geçmiş ve gelecek değerleriyle ortaya koyarak sürdürülebilirlik koşulunu araştırmaktır. Bunun için grafiksel analizlerden, tablo analizlerinden ve ekonometrik bir yöntem olan ARIMA modelinden yararlanılmıştır. ARIMA modeliyle geleceğe yönelik tahminlerde bulunulabildiği için öngörü yöntemi olarak bu model seçilmiştir. Diğer taraftan çalışma 2025 yılına kadar olan döneme yönelik tahminleri içermesi ve konuyu olabildiğince tüm boyutlarıyla ele alması bakımından literatüre katkı sunabilir.

Çalışma beş bölümden oluşmaktadır. İlk bölümde dış borçlar konusuna ilişkin teorik yaklaşımlara değinilmiştir. İkinci bölümde Türkiye'de dış borçların görünümü ve ekonomik büyümeyle ilişkisi analiz edilmeye çalışılmıştır. Çalışmanın bir sonraki bölümündeyse literatür özeti sunulmuştur. İzleyen bölümde de veri seti ve metodoloji tanıtılmıştır. Çalışma ARIMA uygulamasının ve bulguların yer aldığı beşinci bölümle sonlandırılmıştır.

\section{Teorik Çerçeve}

Gelişmekte olan ülkelerde ekonomik kalkınmanın finansmanında dış borçların rolü, İkinci Dünya Savaşından beri önem kazanmış ve bu tür ülkelerin kalkınmaları konusuna gelişmiş ülkelerin ilgilerinin artması ve uluslararası finans kurumlarının kurulması gelişmekte olan ülkelerin borçlanma olanağını arttırmıştır. Günümüzde, gelişmekte olan ülkelerin borçlanmalarının çoğu dış kaynaklardandır ve bu ülkelerin borçlanma sorunu, dış borçlardaki önemli artışlara ilişkin olarak, gittikçe artan şekilde dikkatleri üzerinde toplamaktadır (Ataç, 2006, s. 333). Diğer bir ifadeyle, günümüzde dış borçlanma için uluslararası kurumsal yapı son derece uygundur. Nitekim sermayenin uluslararası dolaşımının önündeki engellerin giderek kalkmasından dolayı gelişmekte olan ülkelerin yanı sıra gelişmiş ülkelerin de sıklıkla dış borçlanmaya gittikleri açıkça görülmektedir.

Bununla birlikte dış borç konusu teoride uzunca bir süredir tartışılmaktadır. İktisadi düşünce okullarında dış borç konusuna yaklaşımlar aşağıda özetlenmeye çalışılmıştır.

Klasik Yaklaşım'da borçlanmaya genellikle sıcak bakılmamıştır (Pınar, 2014, s. 136). Klasikler olağanüstü dönemler dışında borçlanmaya izin vermezler. Sadece savaş, doğal afetler 
ve bir ölçüde büyük bayındırlık yatırımları için borçlanmaya gidilmesi gerektiğini savunmaktadırlar. Bu sayede gelecek nesillere yüklenecek borç yükü büyük ölçekli bayındırlık yatırımlarıyla bir ölçüde telafi edilecektir (Ulusoy, 2007, s. 48). Klasik iktisadın en önemli temsilcilerinden biri olan David Ricardo 'ya göre borçlanma, ülkelerin başka ülkeleri sömürmeleri için icat ettikleri korkunç bir silahtır. Bu nedenle borçlanmaya çok sık başvurulmamalıdır (Öztürk, 2012, s. 30). Klasiklere göre devlet bütçesi denk olmalı ve borçlanma mümkün olduğunca sınırlandırılmalıdır (Ataç, 2006, s. 6). Klasiklerin önerdiği jandarma devlet ekonominin doğal işleyişine müdahale etmemelidir ve diş borçlanma en son çare olarak görülmelidir.

Keynezyen iktisata göre ekonomi klasik iktisatçıların ifade ettiği gibi her zaman tam istihdam denge düzeyinde bulunmayacağından, ekonominin içinde bulunduğu konjonktüre göre devletin tüketim ve yatırım harcamalarını artırması (azaltması), yani efektif talebi bir araç olarak kullanmas1 gerekmektedir (Aktan, 2004, s. 14). Keynes, politikacilara vergilemeden harcama imkânı sağlamaktadır. Artan kamu harcamalarının vergilerle değil, emisyon ve borçlanma ile karşılanması Keynezyen iktisadın mirasıdır (Öztürk, 2012, s. 64). Benzer şekilde, 1929 bunalımı sonrası ortaya çıkan eğilimler ile bazı devresel dalgalanmalara karşı istikrarı sağlamak veya uzun dönemde getirisi yüksek yatırımların finansmanı için borçlanabilineceği savunulmuştur (Pınar, 2014, s. 136). Keynes'e göre devlet toplam harcamayı arttırmak için çeşitli yollarla kaynak sağlayarak elde etmiş olduğu kaynakları talebi canlandıracak şekilde piyasaya sokmalıdır (Mutluer vd., 2007, s. 20). Diğer bir deyişle diş borçlanma eksik istihdam durumunda toplam talebin arttırılmasında kullanılırsa yararlı olabilir.

Monetarizm'in öncüsü Friedman, devletin büyümesi yönündeki eğilimin durdurulmas1 için harcamalar ve vergiler üzerine anayasal sınırlamalar getirilmesini önerir. Friedman'a göre bir ekonomide para arzındaki değişmeler de konjonktürü etkilemektedir. Ekonomi temelde istikrarlıdır ve piyasa kendi haline bırakıldığında kaynakların optimal dağılımı ve üretim kapasitesinin tam kullanımı sağlanacaktır. Bu nedenle devletin müdahalelerinin ekonominin istikrarını bozmaması için denk bütçe uygulanması ve parasal genişlemelerin de üretim artışıyla aynı oranda gerçekleştirilmesi gerekmektedir (Ulusoy, 2007, s. 63-64). Monetaristler kısa dönemli maliye politikasının ekonomide istikrara hizmet etmekten çok istikrarı daha da bozduğunu savunmaktadır (Öztürk, 2012, s. 90). Kısacası monetaristler devletin ekonomiye müdahale etmemesini ve denk bütçe anlayışını savunduklarından dış borçlanmaya olağan dönemlerde başvurulmamasını öne sürmektedirler.

Yapısalcı Yaklaşım'ın savunucuları ekonomilerde görülen yapısal darboğazları belirleme ve analiz etme ile ilgilenmişlerdir. İnceleme konusu yapılan başlıca alanları gıda maddesi (tarımda ürün arzı) yetersizliği, ödemeler bilançosu ve bütçe sinırlamaları oluşturmuştur. Yapısalc1 yaklaşım liberal ekonomi yaklaşımlarının tersine devlet müdahalesinin olduğu bir ekonomik yapıyı önermektedir. Onlara göre kökleri çok eskilere dayanan yapısal bozuklukların giderilebilmesi, kronik enflasyonla mücadele edilmesi kısaca istikrara kavuşulması için aktif müdahalenin gerekli olduğu savunulmaktadır (Ulusoy, 2007, s. 66-71). Sonuç olarak yapisalcı yaklaşım savunucularına göre ekonomiye müdahale etmek için dış borçlanmaya gidilebilir fakat denk bütçe anlayışı çerçevesinde borç alımı mutlaka sınırlı olmalıdır.

Anayasal İktisat Teorisi "devletin gücü ve yetkilerinin nasıl sınırlandırılabileceğini ve nasıl sınırlandırılması gerektiğini" inceleyen bir disiplindir... Borçlanma anayasası devletin iç ve dış borçlanma şartlarını ve buna ilişkin sınırlamaları içermektedir. Mali anayasaların önemli bir alanını da Denk Bütçe Anayasası oluşturmaktadır. Anayasal iktisatçılara göre, klasik iktisadi düşüncede önemli bir yer tutan denk bütçe ilkesine geri dönülmelidir (Aktan, 2004, s. 101-111). Para politikasının yanında maliye politikası da kurala bağlanmalıdır. Bu yaklaşıma göre, mali kural yerine iradi maliye politikası izleyen siyasal iktidarların ekonomiyi politize etme riski daima mevcuttur. Para basma ve borçlanma yetkilerini ellerinde bulunduran siyasal iktidarlar maliye politikasını mali istikrarı sağlamaktan daha çok yeniden seçilebilmeyi garantilemek için bir araç 
olarak kullanmaktadır (Öztürk, 2012, s. 114). Nihayetinde anayasal iktisat teorisine göre dış borçlanma mutlaka kanunlarla sınırlandırılmalıdır.

Arz Yanlı Iktisat, klasik iktisadın ilklerine bağlıdır ve bu yaklaşım genelde vergi indirimleri politikasına ăgırlık verdiğinden aynı zamanda arz yanlı vergi politikası olarak da ifade edilmektedir. Robert Mundell' in başı çektiği arz yanlı iktisatçılar ekonomik istikrarsızlığın ana kaynağını üretim ve arz yetersizliği olarak görürler... Teorinin uygulama sonuçlarına bakıldığında, ABD'de toplanan vergilerden daha fazla harcanmış ve bütçe açıkları artmıştır. Bu nedenle dış borç yükü artmaya devam etmiştir (Ulusoy, 2007, s. 76-81). Minimal devlet anlayışını savunan arz yanlı iktisata göre devlet her alanda olabildiğince küçültülmelidir. Devletin ekonomik yaşamda aktif bir unsur olarak yer almaktan olabildiğince vazgeçmesi, piyasa ekonomisinin gelişmesini, piyasa ekonomisinin gelişmesi de ekonomik davranışların daha akılcı hale gelmesini sağlamaktadır (Öztürk, 2012, s. 77). Sonuç olarak, arz yanlı iktisatçılar devletin ekonomiye müdahale etmesine karşı olduklarından ve minimal devlet anlayışını savunduklarından dış borçlanmaya karşıdırlar.

Yeni Keynezyen Yaklaşım'a temiz olmayan piyasa modeli de denilmektedir. Yeni Keynezyenlere göre piyasaların temiz olmamasının en önemli nedeni ücret ve fiyatların yapışkanlığıdır. Ücretlerin yapışkanlığını sağlayan nedenler zımni sözleşmeler, etkin ücretler, içerdekiler dışarıdakiler vb. gibi durumlardır (Ataç, 2006, s. 25). Yeni Keynezyen teoride durgunluk ekonomide yaygınlaşmış piyasa başarısızlıklarından kaynaklanır. Yeni Keynezyenler bunun devletin ekonomiye müdahale etme gerekçesi olduğunu ileri sürerler (Ulusoy, 2007, s. 93). Yeni Keynezyen model genel olarak Keynes'in görüşlerini desteklemekte dolayısıyla toplam talebin artırılması için devletin ekonomiye müdahale etmek için dış borçlanmaya başvurulmasını uygun görmektedir.

\section{Türkiye'nin Dış Borçları ve Ekonomik Büyüme}

Türkiye selefi Osmanlı Devleti'nden tam anlamıyla harap olmuş ve üretici kaynakları yetersiz olan bir ülke devralmıştır. $O$ yıllarda Batı ise sanayi devrimini gerçekleştirmiş ve ürettiği sanayi ürünleri için hammadde ve pazar arayışına girmiştir. Osmanlı Devleti'nin özellikle 19. yüzyıldan itibaren içine düştüğü bu ekonomik bunalım ülkeyi dış borç batağına doğru sürüklemiştir. İlk dış borç 1854 yılında Kırım Savaşı'nın tahribatı nedeniyle İngiltere'den alınmıştır. Osmanlı'da 1854'ten devletin yıkıldığı 1922 yılına kadar savaşlar ve ekonomik darboğazlar nedeniyle dış borçlar sürekli artmıştır. Türkiye Cumhuriyeti kuruluşunun ilk yıllarından itibaren Osmanlı'dan kalan ve Lozan Antlaşması'yla taksim edilen borç içerisinden üzerine düşen miktarın son taksidini de ancak 1954 yılında ödeyebilmiştir.

Cumhuriyetin ilk yıllarında bir tarım toplumu olan Türkiye az miktardaki iç tasarruflarıyla kendi milli burjuvazisini oluşturmaya çalışmıştır. Bu y1llarda planlı ekonomi benimsenmiş, ülkede sınırlı sayıdaki sanayi kuruluşları millileştirilmiş ve büyük sanayi yatırımları devlet öncülüğünde gerçekleştirilmiştir. Kısacası milli bir ekonomi kurmak amacıyla dış borçlanmaya zorunlu kalmadıkça başvurulmamıştır. Türkiye'nin dış borç serüveninin 195060'lı yıllarda başladığı söylenebilir. Fakat 1980'li yıllara kadar gerek milli ekonomi gerekse planlı ekonomi nedeniyle dış borçlara başvurmak hep en son çare olarak görülmüştür. Fakat özellikle 1970'li yıllardaki petrol şokları, dünya ekonomisinde yaşanan krizler, Kıbrıs Barış Harekâtı'nın getirdiği ekonomik bunalım ve siyasal istikrarsızlıklar bütçe ve cari dengelerde açıklara sebep olmuş ve bu açıklar da dış borçlanmaya başvurularak kapatılmaya çalışılmıştır. 1980 yılından sonra ise dışa açık ekonomik kalkınma modeli benimsenmiş ve bu doğrultuda uluslararası ilişkiler ivme kazanmıştır. Bunun sonucu olarak dış borçların kompozisyonunda ve miktarında istikrarlı bir artış meydana gelmiştir. Nitekim bu yıllarda sermaye birikimi ve iç tasarrufları yetersiz olan Türkiye'de dış borçların ekonomik büyümeye katkı sağlayabileceği ortaya konulmuştur. 1990'lı yıllarda ise siyasi ve ekonomik istikrarsızlıklar ve cari açık nedeniyle dış borçlanmaya gitme tercihi iyice belirginleşmiştir. 2000'li yıllara gelindiğinde ise dış borçlar diğer gelişmekte olan 
ülkelerde olduğu gibi mali açıkların kapatılması için ve kalkınma aracı olarak kullanılmaya başlanmıştır. Dolayısıyla dış borç servis oranı Türkiye için kritik bir öneme sahip olmuştur.

Türkiye'nin 1990-2016 diş borç görünümü Tablo 1'de sunulmuştur.

Tablo 1. Türkiye’nin 1990-2016 dönemi dış borç görünümü (Milyon ABD doları)

\begin{tabular}{|c|c|c|c|c|c|}
\hline & $\begin{array}{c}\text { KAMU } \\
\text { SEKTÖRÜ (I) }\end{array}$ & $\begin{array}{c}\text { ÖZEL } \\
\text { SEKTÖR (II) }\end{array}$ & $\begin{array}{l}\text { TCMB } \\
\text { (III) }\end{array}$ & $\begin{array}{c}\text { TÜRKIYE BRÜT } \\
\text { DIŞ BORÇ STOKU } \\
\text { (I+II+III) }\end{array}$ & $\begin{array}{c}\text { TÜRKIYYE } \\
\text { BRÜT DIŞ } \\
\text { BORÇ } \\
\text { STOKU/GS }\end{array}$ \\
\hline 1990 & 33.268 & 10.770 & 8.342 & 52.381 & 26,1 \\
\hline 1991 & 35.280 & 11.128 & 7.215 & 53.623 & 26,7 \\
\hline 1992 & 36.476 & 15.390 & 6.730 & 58.595 & 27,8 \\
\hline 1993 & 39.640 & 23.579 & 7.293 & 70.512 & 29,6 \\
\hline 1994 & 41.741 & 17.186 & 9.777 & 68.705 & 38,8 \\
\hline 1995 & 42.003 & 21.774 & 12.171 & 75.948 & 33,6 \\
\hline 1996 & 40.192 & 26.725 & 12.381 & 79.299 & 32,6 \\
\hline 1997 & 39.068 & 33.523 & 11.765 & 84.356 & 33,2 \\
\hline 1998 & 41.339 & 42.026 & 12.986 & 96.351 & 34,7 \\
\hline 1999 & 44.107 & 48.011 & 11.006 & 103.123 & 40,7 \\
\hline 2000 & 50.081 & 54.431 & 14.090 & 118.602 & 43,6 \\
\hline 2001 & 47.129 & 42.112 & 24.351 & 113.592 & 56,5 \\
\hline 2002 & 64.533 & 43.066 & 22.003 & 129.601 & 54,8 \\
\hline 2003 & 70.844 & 48.956 & 24.373 & 144.172 & 45,9 \\
\hline 2004 & 75.668 & 64.076 & 21.410 & 161.154 & 40,0 \\
\hline 2005 & 70.411 & 84.920 & 15.425 & 170.757 & 34,2 \\
\hline 2006 & 71.587 & 120.737 & 15.678 & 208.002 & 38,0 \\
\hline 2007 & 73.525 & 160.600 & 15.801 & 249.926 & 36,9 \\
\hline 2008 & 78.334 & 188.374 & 14.066 & 280.774 & 36,2 \\
\hline 2009 & 83.513 & 172.023 & 13.162 & 268.698 & 41,5 \\
\hline 2010 & 89.109 & 190.971 & 11.565 & 291.645 & 37,8 \\
\hline 2011 & 94.279 & 200.065 & 9.334 & 303.678 & 36,5 \\
\hline 2012 & 104.023 & 228.383 & 7.088 & 339.494 & 39,0 \\
\hline 2013 & 115.945 & 268.505 & 5.234 & 389.684 & 41,0 \\
\hline 2014 & 117.687 & 281.557 & 2.484 & 401.728 & 43,0 \\
\hline 2015 & 113.097 & 281.437 & 1.327 & 395.862 & 46,0 \\
\hline 2016 & 119.715 & 284.354 & 821 & 404.890 & 47,3 \\
\hline
\end{tabular}

Kaynak: Hazine Müsteşarll̆ğ

Tablo 1'e göre 1990 yılında 33 milyar dolar olan kamu sektörü dış borcu yıllık ortalama \% 5,34 artarak 2016 yılında 119 milyar dolara ulaşmıştır. Aynı dönemde özel sektör dış borcuysa 10 milyar dolardan yıllık ortalama \% 14,97 artışla 284 milyar dolara çıkmıştır. Diğer taraftan 2000-2016 yılları arası yıllık dış borç artış hızı kamu kesimi için \% 6,84; özel sektör içinse \% 12,95'tir. TCMB'nin dış borcuna bakıldığındaysa 1995-2005 yılları arasında rakamın 15-20 milyar dolar seviyesine kadar çıtı̆̆ 1 diğer yıllardaysa nispeten düşük seviyede gerçekleştiği görülmektedir. Tüm bu göstergelere göre Türkiye'de özellikle özel sektör dış borçlarının daha sonraysa kamu sektörü dış borçlarının anılan dönemdeki yıllık ekonomik büyüme oranlarının üzerinde gerçekleştiği söylenebilir. Nitekim Tablo 2.1'in son sütunundaki "Brüt Diş Borç Stoku/GSYIH" değerlerinin artış eğilimi içerisinde olması da bu saptamayı doğrular niteliktedir. $\mathrm{Bu}$ noktada Türkiye'nin dış borç oranlarındaki bu yüksek artışın daha sağlıklı bir şekilde değerlendirilebilmesi için uluslararası karşılaştırmaların yapılması kaçınılmazdır. Söz konusu 
karşılaştırma için gelişmekte olan BRICS-T ülkelerindeki “Dış Borç/GSYİH” oranları Tablo 2’de sunulmuştur.

\begin{tabular}{llccc}
\multicolumn{4}{l}{ Tablo 2. BRICS-T ülkelerinde diş borç/GSYİH oranları (2016 y1li) } \\
\hline $\begin{array}{l}\text { BRICS-T } \\
\text { Ülkeleri }\end{array}$ & $\begin{array}{c}\text { D1ş Borç } \\
\text { (Milyon Dolar) }\end{array}$ & $\begin{array}{c}\text { GSYİH } \\
\text { (Milyon Dolar) }\end{array}$ & $\begin{array}{c}\text { Diş Borç/GSYİH } \\
\text { (\%) }\end{array}$ \\
\hline 1 & Güney Afrika & 146.040 & 295.456 & 49,4 \\
2 & Türkiye & 405.656 & 863.711 & 47,0 \\
3 & Rusya & 524.685 & 1.283 .162 & 40,9 \\
4 & Brezilya & 543.257 & 1.796 .186 & 30,2 \\
5 & Hindistan & 456.139 & 2.263 .792 & 20,1 \\
6 & ÇHC & 1.429 .467 & 11.199 .145 & 12,8 \\
\hline
\end{tabular}

Kaynak: Dünya Bankası

Tablo 2'ye göre BRICS-T ülkeleri arasında Türkiye en yüksek borçlanma oranı bakımından ikinci sıradadır. Bu tabloya göre gelişmekte olan BRICS-T ülkelerinde yüksek dış borçlanma görülmektedir. Fakat Tablo'daki veriler Türkiye'nin dış borçlanma konusunda hassas bir seviyeye geldiğini de hatırlatmaktadır. Yine de ilgili Tablo'nun genel görünümüne bakılırsa dış borçlar açısından olağanüstü kötü bir durumun olmadığı ve etkin bir borç yönetimiyle Türkiye'nin dış borçlarını sürdürebilmekte başarılı olacağı ileri sürülebilir. Fakat 2017 yılı üçüncü çeyreği itibarıyla Türkiye'de "Dış Borç/GSYIH'”" oranının \% 50'nin üzerine çıktığı düşünülürse dış borçlanma açısından Türkiye'nin BRICS-T ülkeleri arasında bugün en kötü durumda olduğu söylenebilir.

Türkiye'nin dış borçlarının genel görünümünün sunulduğu Tablo 2.1'den Türkiye'de son yıllarda özellikle özel kesim dış borçlarının ciddi bir artış eğiliminde olduğu görülmektedir. Özel kesim dış borçları Türkiye Cumhuriyeti Hazine Müsteşarlı̆̆ı'nın tanımıyla finansal kuruluşlar, özellikle bankalar ve reel kesim borçları olmak üzere iki ana başlığa ayrılır. Türkiye'nin özel kesim dış borçlarının 1990-2016 yılları arası görünümü Grafik 1'de sunulmuştur.

Grafik 1. Türkiye'de özel kesim dış borçlarının görünümü (Milyon ABD doları)

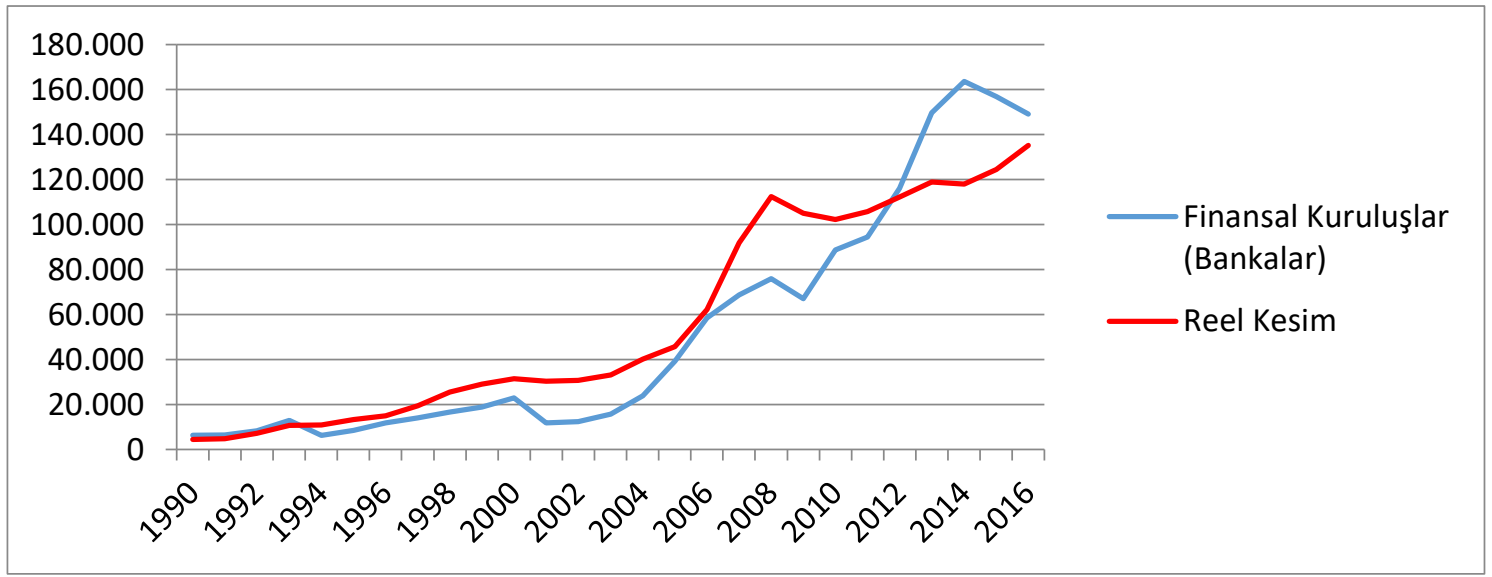

Kaynak: Hazine Müsteşarlığ1

Grafik 1'den Türkiye'de özellikle 2002 yılından sonra özel kesim yani bankalar ve reel kesim dış borçlarının önemli ölçüde arttığı görülmektedir. Grafiğge göre dünya ekonomisinin ya da ülke ekonomisinin durgunluk dönemlerinde (2001 Türkiye ekonomik krizi, 2008 Dünya ekonomik krizi, 2015 Dünya ekonomik durgunluğu vs. ) finansal kuruluşların diş borç talebi nispeten azalmakta fakat reel kesimin dış borç talebi artmaktadır. Kısacası Türkiye'de finansal 
kuruluşlar ekonomideki güven unsurunu temel alarak dış borçlanmaya giderken, reel kesim zorda kaldığı dönemlerde dış borç alımına başvurmuştur. Sonuç olarak 2002 yılından sonra Türkiye'de yaşanan siyasi istikrarla ekonomiye olan güvenin artmasıyla finansal kuruluşlar ve reel kesim daha sık dış borçlanmaya başvurmuştur denilebilir.

Bir ülkede dış borçların sürdürülebilirliği açısından bir diğer önemli husus dış borcun ağırlığının kısa vadeli mi yoksa uzun vadeli mi olduğudur. Türkiye'nin 1990-2016 dönemi diş borçlarının vade ağırlıkları Tablo 3'te sunulmuştur.

Tablo 3. Türkiye'de dış borcun kısa ve uzun vade ağırlıkları (\%)

\begin{tabular}{ccccc}
\hline & \multicolumn{2}{c}{ KISA VADE } & \multicolumn{2}{c}{ UZUN VADE } \\
\hline & $\begin{array}{c}\text { Dış Borç } \\
\text { (Milyon \$) }\end{array}$ & $\begin{array}{c}\text { Toplam İçindeki } \\
\text { Pay (\%) }\end{array}$ & $\begin{array}{c}\text { Dış Borç } \\
\text { (Milyon \$) }\end{array}$ & $\begin{array}{c}\text { Toplam İçindeki } \\
\text { Pay (\%) }\end{array}$ \\
\cline { 2 - 5 } 1990 & 9.500 & 18,1 & 42.881 & 81,9 \\
1995 & 15.500 & 20,4 & 60.448 & 79,6 \\
2000 & 28.301 & 23,9 & 90.301 & 76,1 \\
2005 & 38.914 & 22,8 & 131.843 & 77,2 \\
2010 & 77.232 & 26,5 & 214.413 & 73,5 \\
2015 & 101.880 & 25,7 & 293.982 & 74,3 \\
2016 & 98.009 & 24,2 & 306.881 & 75,8 \\
Ortalama & - & $\mathbf{2 3 , 0 8}$ & - & $\mathbf{7 6 , 9 1}$ \\
$(\%)$ & & & & \\
\hline
\end{tabular}

Kaynak: Hazine Müsteşarlığ 1

Tablo 3'e göre Türkiye'nin dış borçlarının genel olarak dörtte üçü uzun vadeli kredilerden ve kalan dörtte biri de kısa vadeli kredilerden oluşmaktadır. Daha da önemlisi bu oranların son otuz yıldır benzer olduğu yani kısa veya uzun vadeli dış borç kompozisyonunda ciddi bir değişimin olmadığı görülmektedir. Diğer bir deyişle günümüzde kısa vade veya uzun vadeli dış borç ağırlığı açısından olağanüstü bir durumun söz konusu olmadığı Tablo 2.3’ten açıkça görülmektedir.

Kuşkusuz ki dış borç yönetimi açısından bir diğer önemli husus borcun hangi para biriminden (Dolar, Euro, vs.) olduğudur. Türkiye Merkezi Yönetim'in dış borç stokunun döviz kompozisyonu Tablo 4'te sunulmuştur.

Tablo 4. Merkezi yönetim dış borç stokunun döviz yapısı

\begin{tabular}{cccccccccccc}
\hline & \multicolumn{3}{c}{ DOLAR $(\$)$} & \multicolumn{2}{c}{ EURO $(€)$} & \multicolumn{2}{c}{ YEN $(¥)$} & \multicolumn{2}{c}{ SDR $($ IMF) } & \multicolumn{2}{c}{ DİĞER } \\
\hline & $\begin{array}{l}\text { Miktar } \\
(\text { Milyon }\end{array}$ & $\begin{array}{l}\text { Pay } \\
(\boldsymbol{\%})\end{array}$ & $\begin{array}{c}\text { Miktar } \\
(\text { Milyon }\end{array}$ & $\begin{array}{c}\text { Pay } \\
(\boldsymbol{\%})\end{array}$ & $\begin{array}{c}\text { Miktar } \\
(\text { Milyon }\end{array}$ & $\begin{array}{c}\text { Pay } \\
(\boldsymbol{\%})\end{array}$ & $\begin{array}{c}\text { Miktar } \\
(\text { Milyon }\end{array}$ & $\begin{array}{c}\text { Pay } \\
(\boldsymbol{\%})\end{array}$ & $\begin{array}{c}\text { Miktar } \\
(\text { Milyon }\end{array}$ & $\begin{array}{c}\text { Pay } \\
(\boldsymbol{\%})\end{array}$ \\
\hline 2003 & 35.292 & 39,7 & 23.229 & 26,1 & 5.247 & 5,9 & 23.478 & 26,4 & 1.601 & 1,8 \\
2005 & 42.158 & 51,5 & 21.149 & 25,8 & 3.110 & 3,8 & 14.653 & 17,9 & 729 & 0,8 \\
2010 & 66.515 & 54,9 & 36.348 & 30,0 & 6.447 & 5,3 & 11.065 & 9,1 & 599 & 0,4 \\
2015 & 148.433 & $\mathbf{6 2 , 7}$ & 67.091 & 28,3 & 16.387 & 6,9 & 3.951 & 1,6 & 775 & 0,3 \\
2016 & 191.101 & $\mathbf{6 5 , 8}$ & 74.291 & $\mathbf{2 5 , 6}$ & 19.815 & $\mathbf{6 , 8}$ & 4.655 & $\mathbf{1 , 6}$ & 330 & $\mathbf{0 . 1}$ \\
\hline
\end{tabular}

Kaynak: Hazine Müsteşarlı̆̆ 1

Tablo 4'e göre Türkiye'de dış borçlar 2003 yılından günümüze “ABD doları" ağırlıklı olmuştur. Nitekim 2003 yılı dış borçları içerisinde Doların ağırlığ $1 \% 39,7$ iken 2016 yılında bu oran \% 65'8 olarak gerçekleşmiştir. Tablo 4'e göre dış borçlar içerisinde Euro'nun ağırlığıysa 
özellikle 2010 yılından sonra azalma eğilimine girmiştir. Yine geleneksel ödeme araçları olan Dolar ve Euro'nun yanı sıra Japon Yeni'nin de yaklaşık \% 6 pay ile dış borç döviz birimi olarak kullanıldığı dikkati çekmektedir. Tablodan elde edilen bir diğer sonuç SDR'nin yani Uluslararası Para Fonu (IMF) tanımlı para biriminin ağırlığının IMF'ye olan borçların 2003 yılından itibaren kapatılması nedeniyle hızla azalma eğiliminde olduğudur. Son olarak Tablo 2.4'e göre diğer para birimleriyle borçlanma oranları çok düşüktür ve bu oran giderek daha da azalma eğilimindedir.

D1ş borç stokunun bir ülke ekonomisi için tehlike sinyalleri verip vermediği o ülkenin ekonomik büyüme oranlarıyla karşılaştırılarak sağlıklı bir şekilde yapılabilir. Grafik 2.2'de Türkiye'de 1990-2016 yılları arası dış borç stoku ve ekonomik büyüme arasındaki ilişki gösterilmiştir.

Grafik 2. Türkiye'de 1990-2016 dönemi dış borç stoku artış hızı ve ekonomik büyüme oranları

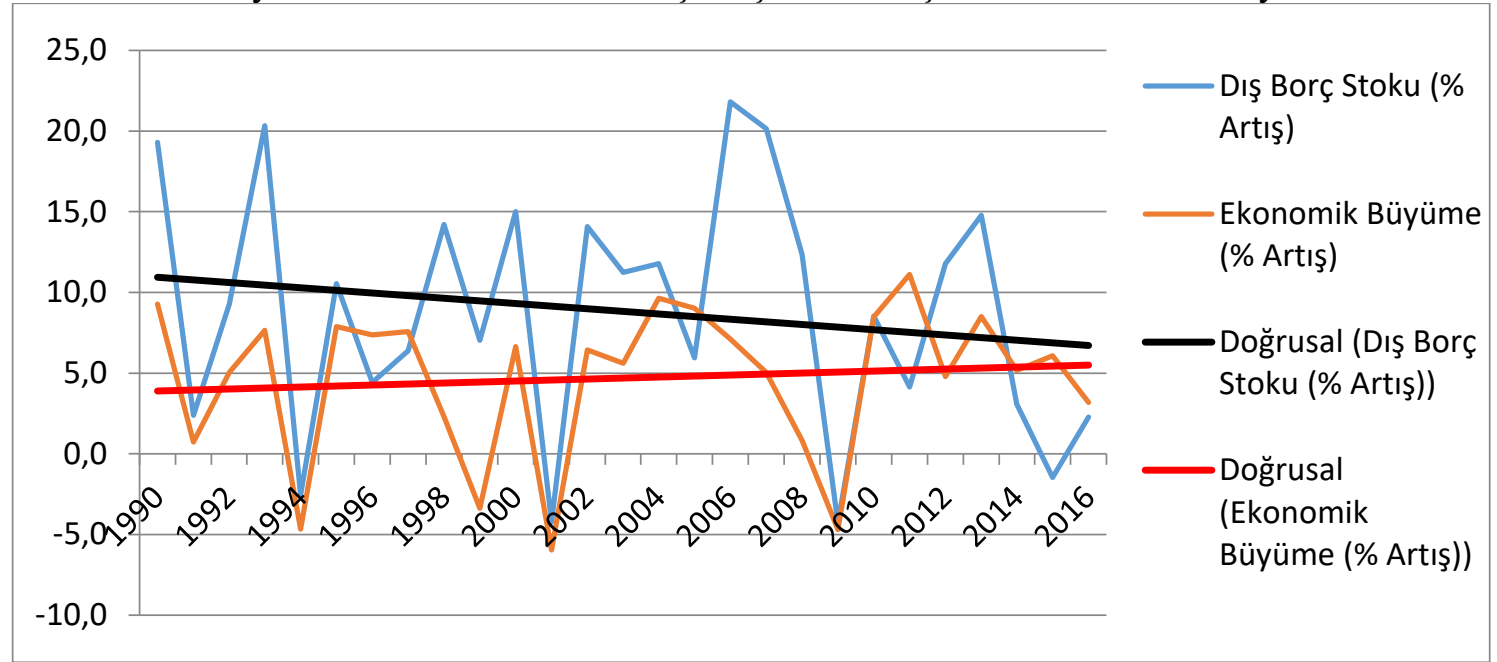

Kaynak: Hazine Müsteşarlığı, Dünya Bankası

Grafik 2'ye göre 1990-2016 döneminde Türkiye'de dış borç artış oranı genel olarak ekonomik büyüme oranlarının üzerindedir. $\mathrm{Bu}$ görünüm şüphesiz ki ülke risk primini arttırmaktadır. Buna ek olarak yine genel itibarıyla dış borç artış oranlarının seyri ve ekonomik büyüme oranlarının seyri arasında benzerlik olduğu söylenebilir. Diğer taraftan anılan dönemde gerek dış borç artış oranları gerekse ekonomik büyüme oranları yüksek derecede dalgalıdır. Yani Türkiye ekonomisinde 1990-2016 yılları arasında sert ve keskin inişlerin ve çıkışların olduğu görülmektedir. Bu yüksek standart sapmaların bir kısm1 "1994 Krizi" ve "2001 Krizi" gibi kısmen yerel kaynaklı olduğu gibi bir kısmı da "1998 Asya Krizi" ve "2008 Küresel Ekonomik Krizi" gibi doğrudan dış kaynaklıdır. Grafik 2'deki eğilim çizgilerine bakıldığındaysa dış borç artış oranının (siyah çizgi) yüzde onların üzerinden yüzde beşlere kadar düştüğü, ekonomik büyüme oranlarınınsa (kırmızı çizgi) yüzde beşler seviyesinde olduğu ve az da olsa pozitif yönde bir iyileşme olduğu görülmektedir.

\section{Literatür Taraması}

Dış borçların sürdürülebilirliği ve ekonomik büyümeye etkisi literatürde uzunca bir süredir incelenmektedir. Bazı çalışmalarda çeşitli ülkeler açısından dış borçların sürdürülebilir olduğu kanaatine varılmışken bazı çalışmalardaysa dış borçların sürdürülemez olduğu kanaatine varılmıştır. Benzer şekilde birçok çalışmaya göre dış borçlar ülkelerin ekonomik büyümeleri üzerinde negatif etkiye sahipken, diğer çalışmalardaysa dış borçların ekonomik büyüme üzerinde pozitif etkisinin olduğu görülmüştür. Bununla birlikte literatüre göre dış borçların ödemeler dengesi üzerinde, kalkınma üzerinde, fiyatlar genel seviyesi üzerinde, gelir dağılımı üzerinde vs. önemli etkileri bulunmaktadır. Bu bölümde özellikle dış borçların sürdürülebilirliği ve ekonomik büyümeye etkisini konu edinen literatürden örnekler sunulacaktır. 
Türkiye'de dış borçların sürdürülebilirliği konusunu araştıran Azgün'ün (2005) zamanlararası bütçe kısıtı testlerini kullandığı çalışmasında 1981-2004 dönemi incelenmiş ve sonuç olarak geri ödeme yeteneği koşulunun sağlandığı ortaya konulmuştur. Buna göre Türkiye söz konusu dönemde dış borç yönetiminde başarılıdır. Diğer bir deyişle borçlar sürdürülebilirdir.

Yavuz ve Çiçek (2006), çalışmalarında Türkiye'nin 1994-2005 dönemi dış borçlarını rasyo analizleriyle incelemişlerdir. Kullanılan yöntem dış borç stokunun temel ekonomik büyüklüklere oranlanmasını içermektedir. Çalışmada Türkiye'nin dış borç stokundaki artışların tek bir nedeninin var olmadığı ve ortalama olarak uluslararası kriterlerden yüksek olduğu sonucuna ulaşılmıştır. Bu sonuç Azgün'ün (2005) Türkiye'de dış borçlar sürdürülebilir sonucuyla kısmen de olsa çelişmektedir.

Yılancı ve Özcan (2008), çalışmasında Türkiye'de dış borçların 1990-2007 dönemini doğrusal olmayan yöntemlerle incelemiş ve dış borçların sürdürebilir olmadığını gösteren kanıtlara ulaşmıştır. Bu sonuç Azgün'ün (2005) çalışmasıyla çelişmekte, Yavuz ve Çiçek'in (2006) çalışmasıylaysa aynı doğrultudadır.

Bununla birlikte Osmanlı Devleti'nden günümüze Türkiye'de dış borçların serüvenini inceleyen Yavuz (2009) çalışmasında 2001 yılına kadar dış borç yönetiminin etkin olmadığını ve bu tarihten sonra uygulanan mali disiplinle dış borçların uluslararası kriterler açısından makul düzeye geldiğini ve sürdürülebilir hale geldiğini vurgulamıştır.

Literatürde dış borçların nedenleri de araştııılmıştır. Nitekim Türkiye'de dış borçların belirleyicilerini ekonometrik yöntemlerle araştıran Peker ve Bölükbaş (2013), çalışmalarında 1994-2010 döneminde iç borçların ve 2001-2010 dönemindeyse kamu harcamalarının başlıca dış borç nedeni olduğunu saptamışlardır.

Diğer taraftan Akan ve Kanca (2015), çalışmalarında dış borçlarla ekonomik büyüme ve enflasyon arasındaki ilişkileri incelemişler ve Türkiye' de büyümeden diş borçlara doğru tek yönlü bir nedenselliğin olduğunu bulgulamışlardır. Çalışmada ayrıca varyans ayrıştırması sonucunda dış borç stokundaki değişimin enflasyon üzerinde anlamlı bir etkiye sahip olduğu sonucuna ulaşılmıştır.

Dış borçlanma ve ekonomik büyüme ilişkisini inceleyen ampirik literatür özeti ise aşağıdaki tabloda (Tablo 5) sunulmuştur. 
Tablo 5. Dıș borç ekonomik büyüme ilişkisini araştıran ulusal ve uluslararası ampirik literatür

\begin{tabular}{|c|c|c|c|c|}
\hline Yazar(lar) & Ülke(ler) & Dönem & Yöntem & Sonuç \\
\hline A. Schclarek (2004) & $\begin{array}{l}24 \text { Gelişmiş } \\
\text { Ülke }\end{array}$ & $1970-2002$ & $\begin{array}{l}\text { Dinamik Panel Veri } \\
\text { Analizi }\end{array}$ & $\begin{array}{l}\text { Hükümet borçları ile ekonomik büyüme } \\
\text { arasında anlamlı bir ilişki yoktur. }\end{array}$ \\
\hline $\begin{array}{l}\text { Bilginoğlu ve Aysu } \\
\text { (2008) }\end{array}$ & Türkiye & $1968-2005$ & Regresyon Analizi & $\begin{array}{l}\text { Türkiye'de diş borçlar uzun dönemde } \\
\text { ekonomik büyüme üzerinde olumsuz etkiye } \\
\text { sahiptir. }\end{array}$ \\
\hline Uysal vd. (2009) & Türkiye & $1965-2007$ & VAR Analizi & $\begin{array}{l}\text { D1ş borçlar kısa ve uzun vadede ekonomik } \\
\text { büyüme üzerinde negatif etkiye sahiptir. }\end{array}$ \\
\hline Malik vd. (2010) & Pakistan & $1972-2005$ & En Küçük Kareler & $\begin{array}{l}\text { Diş borç stoku ekonomik büyüme oranları } \\
\text { üzerinde önemli ölçüde azaltıcı bir etkiye } \\
\text { sahiptir. }\end{array}$ \\
\hline $\begin{array}{l}\text { Çöğürcü ve Çoban } \\
\text { (2011) }\end{array}$ & Türkiye & 1980-2009 & $\begin{array}{l}\text { Eşbütünleşme ve } \\
\text { Regresyon Analizi }\end{array}$ & $\begin{array}{l}\text { D1ş borçlar ekonomik büyüme üzerinde } \\
\text { negatif etkiye sahiptir. }\end{array}$ \\
\hline $\begin{array}{l}\text { C. C. Westphal ve P. } \\
\text { Rother (2012) }\end{array}$ & $\begin{array}{l}12 \text { Euro } \\
\text { Bölgesi } \\
\text { Ülkesi }\end{array}$ & $1970-2010$ & $\begin{array}{l}\text { Eşbütünleşme ve En } \\
\text { Küçük Kareler }\end{array}$ & $\begin{array}{l}\text { Hükümet borçları ekonomik büyüme } \\
\text { üzerinde negatif etkiye sahiptir. }\end{array}$ \\
\hline Nawaz vd. (2012) & Pakistan & $1980-2010$ & $\begin{array}{l}\text { Eşbütünleşme ve } \\
\text { Granger Nedensellik }\end{array}$ & $\begin{array}{l}\text { D1ş borçlarla ekonomik büyüme uzun } \\
\text { dönemde eşbütünleşiktir. Kısa dönemde iki } \\
\text { değişken arasında çift yönlü nedensellik } \\
\text { vardır. }\end{array}$ \\
\hline Umaru vd. (2013) & Nijerya & $1970-2010$ & $\begin{array}{l}\text { En Küçük Kareler ve } \\
\text { Granger Nedensellik }\end{array}$ & $\begin{array}{l}\text { Diş borçlarla ekonomik büyüme arasında } \\
\text { çift yönlü nedensellik vardır. Dış borçlar } \\
\text { ekonomik büyümeyi negatif etkilemektedir. }\end{array}$ \\
\hline $\begin{array}{l}\text { J. Mencinger vd. } \\
\text { (2014) }\end{array}$ & $\begin{array}{l}25 \text { Avrupa } \\
\text { Birliği Ülkesi }\end{array}$ & $1980-2010$ & Panel Veri Analizi & $\begin{array}{l}\text { Kişi başı ekonomik büyüme oranları } \\
\text { üzerinde dış borç oranının anlamlı bir etkisi } \\
\text { vardır. }\end{array}$ \\
\hline $\begin{array}{l}\text { A. Afonso ve J. Alves } \\
\text { (2014) }\end{array}$ & $\begin{array}{l}14 \text { Avrupa } \\
\text { Ülkesi }\end{array}$ & $1970-2012$ & $\begin{array}{l}\text { Regresyon ve Eşik } \\
\text { (Thresholds) Etkisi } \\
\text { Analizi }\end{array}$ & $\begin{array}{l}\text { D1ş borçların artması ekonomik büyüme } \\
\text { üzerinde negatif etkiye sahiptir. }\end{array}$ \\
\hline Bal ve Rath (2014) & Hindistan & 1980-2011 & $\begin{array}{l}\text { ARDL Sinır Testi ve } \\
\text { ECM }\end{array}$ & $\begin{array}{l}\text { Dış borçlar ile ekonomik büyüme arasında } \\
\text { hem kısa hem de uzun dönemde ilişki } \\
\text { vardır. }\end{array}$ \\
\hline Arslan (2014) & Pakistan & 1972-2010 & En Küçük Kareler & $\begin{array}{l}\text { D1ş borçlar ekonomik büyümeyi pozitif } \\
\text { etkilemektedir. }\end{array}$ \\
\hline Bittencourt (2015) & $\begin{array}{l}\text { Güney } \\
\text { Amerika } \\
\text { Ülkeleri }\end{array}$ & $1970-2007$ & Panel Veri Analizi & $\begin{array}{l}\text { Ekonomik büyüme bölgedeki dış borç } \\
\text { oranlarını önemli ölçüde azaltmaktadır. }\end{array}$ \\
\hline $\begin{array}{l}\text { Gürdal ve Yavuz } \\
\text { (2015) }\end{array}$ & Türkiye & $1990-2013$ & $\begin{array}{l}\text { Gregory-Hansen } \\
\text { Eşbütünleşme ve } \\
\text { Hacker ve Hatemi-J } \\
\text { Nedensellik }\end{array}$ & $\begin{array}{l}\text { Diş borçlanma ile ekonomik büyüme } \\
\text { arasında eşbütünleşme ilişkisi vardır. } \\
\text { Ekonomik büyümeden dış borca doğru tek } \\
\text { vönlü nedensellik vardır. }\end{array}$ \\
\hline $\begin{array}{l}\text { Lee ve Ling Ng } \\
(2015)\end{array}$ & Malezya & 1991-2013 & $\begin{array}{l}\text { Korelasyon ve } \\
\text { Regresyon Analizi }\end{array}$ & $\begin{array}{l}\text { Diş borçlar ekonomik büyüme üzerinde } \\
\text { negatif etkiye sahiptir. }\end{array}$ \\
\hline $\begin{array}{l}\text { Kutlu ve Yurttagüler } \\
\text { (2016) }\end{array}$ & Türkiye & 1998-2014 & Granger Nedensellik & $\begin{array}{l}\text { D1ş borçlardan ekonomik büyümeye doğru } \\
\text { tek yönlü nedensellik vardır. }\end{array}$ \\
\hline Siddique (2016) & $\begin{array}{l}\text { Yoksul } \\
\text { Ülkeler }\end{array}$ & $1970-2007$ & $\begin{array}{l}\text { Dinamik Panel Veri } \\
\text { Analizi }\end{array}$ & $\begin{array}{l}\text { D1ş borçlar ekonomik büyüme üzerinde } \\
\text { negatif etkiye sahiptir. }\end{array}$ \\
\hline $\begin{array}{l}\text { Tülümce ve Yavuz } \\
\text { (2017) }\end{array}$ & Türkiye & 1986-2016 & $\begin{array}{l}\text { ARDL Sinır Testi ve } \\
\text { VAR Analizi }\end{array}$ & $\begin{array}{l}\text { D1ş borçlar ve ekonomik büyüme kısa ve } \\
\text { uzun dönemde eşbütünleşiktir. Diş } \\
\text { borçların ekonomik büyüme üzerinde } \\
\text { negatif etkisi vardır. }\end{array}$ \\
\hline $\begin{array}{l}\text { Akinwunmi ve } \\
\text { Adekoya (2018) }\end{array}$ & Nijerya & $1985-2015$ & $\begin{array}{l}\text { En Küçük Kareler ve } \\
\text { Eşbütünleşme }\end{array}$ & $\begin{array}{l}\text { D1ş borçlar ekonomik büyümeyi önemli } \\
\text { ölçüde olumsuz etkilemektedir. }\end{array}$ \\
\hline $\begin{array}{l}\text { Chirwa ve Odhiambo } \\
\text { (2018) }\end{array}$ & $\begin{array}{l}10 \text { Avrupa } \\
\text { Ülkesi }\end{array}$ & $1970-2018$ & Panel ARDL & $\begin{array}{l}\text { Ekonomik büyüme dış borçlar üzerinde } \\
\text { azaltıcı etki yaratmaktadır. }\end{array}$ \\
\hline
\end{tabular}

Tablo 5’ten de görüldüğü üzere dış borç (anapara ve faiz ödemeleri) genel olarak ekonomik büyüme üzerinde negatif etkiye sahiptir. Buna ek olarak ekonomik büyüme performansı arttıkça dış borç stokunun da azalış eğiliminde olduğu ampirik olarak kanıtlanmıştır. 


\section{Veri Seti ve Metodoloji}

$\mathrm{Bu}$ çalışma bir zaman serisi analizidir. Zaman serileri belirli bir zaman aralığında günlük, aylık, üçer aylık, yıllık vs. ölçümlenmiş veri kümeleri yardımıyla geleceği tahminlemeye yardımcı olurlar ya da seriler arasındaki nedensellik ilişkilerini incelemektedirler. Diğer bir deyişle zaman serileri analizleriyle geçmiş dönem değerlerinin doğrusal ya da doğrusal olmayan şekilde hareket edeceği varsayılarak gelecekteki değerler tahminlenebilir.

\subsection{Veri Seti}

Analizlerde kullanılan değişkenlerin tanımlanması ve veri kaynakları Tablo 6'da sunulmuştur.

Tablo 6. Verilerin tanımlanması ve veri kaynakları

\begin{tabular}{llccc}
\hline Değişken & Açıklama & Gözlem & $\begin{array}{c}\text { Dönem } \\
\text { (Yıllı) }\end{array}$ & Veri Kaynağı \\
\hline DEBT & $\begin{array}{l}\text { Dış Borç Stoku (Cari Fiyatlarla } \\
\text { Milyon ABD Doları) }\end{array}$ & 27 & $1990-2016$ & Hazine Müsteşarlı̆ğ \\
GDP & $\begin{array}{l}\text { Gayri Safi Yurtiçi Hâsıla (Cari } \\
\text { Fiyatlarla Milyon ABD doları) }\end{array}$ & 27 & $1990-2016$ & $\begin{array}{l}\text { World Bank Data } \\
\text { (Dünya Bankası) }\end{array}$ \\
EX & $\begin{array}{l}\text { İhracat (Cari Fiyatlarla Milyon } \\
\text { ABD Doları) }\end{array}$ & 27 & $1990-2016$ & $\begin{array}{c}\text { WTO (Dünya Ticaret } \\
\text { Örgütü) }\end{array}$ \\
\hline
\end{tabular}

Çalışmada yıllık verilerle analizler yapılacaktır. Bu nedenle verilere herhangi bir mevsimsel düzeltme yapılmasına gerek yoktur. İzleyen bölümde ARIMA yöntemiyle değişkenlerin 2017-2025 dönem aralığ tahminlenecektir. Çalışmada orijinal gözlemlerin seyri tahminlendiği ve sonuç olarak serilerin oranları alınarak yorumlandığı için verilere reelleştirme işlemi uygulanmamıştır. Analizlerde E-Views paket programından yararlanılmıştır.

\subsection{Metodoloji}

Klasik regresyon analizi değişkenler arasındaki ilişkiyi göstermektedir. Otoregresif modellerse regresyon analizini zaman serilerine uygulanmasını ifade eder. İstatistiksel analiz yöntemlerinin temeli diyebileceğimiz regresyon analizinde bağımlı değişken yani tahmini yapılacak olan değişken "Y"; $X_{1}, X_{2}, \ldots \ldots X_{k}$ gibi k sayıdaki bağımsız yani açıklayıcı değişkenin bir fonksiyonudur.

$$
Y=a+\beta_{1} X_{1}+\beta_{2} X_{2}+\ldots+\beta_{k} X_{k}+e
$$

Regresyon denkleminde bağımsız değişkenlerin bağımlı değişkenin gecikmeli değerleri olan modellere otoregresif modeller denir. Diğer bir deyişle bu modellerde serinin geçmiş değerlerinin bir uzantısı olduğu varsayılır. Bu çalışmada kullanılan ARIMA (Box-Jenkins) modeli de bir otoregresif modeldir. Toplam dış borçlar, ekonomik büyüme ve ihracat değişkenlerinin geçmiş değerlerinden faydalanılarak gelecek değerleri tahmin edilecektir.

ARIMA modeli otoregresif modeller (AR) ve hareketli ortalamalar modelinin (MA) bütünleşmeyi de içeren bileşimidir (Box ve Jenkins, 1976: 2-4).

Otoregresif Modeller (AR):

$$
Y=\delta_{1} Y_{t-1}+\delta_{2} Y_{t-2}+\ldots+\delta_{p} Y_{t-p}+e_{t}
$$

şeklinde ifade edilirken,

Hareketli Ortalamalar Modeli (MA): 


$$
Y=e_{t}-\lambda_{1} e_{t-1}-\lambda_{2} e_{t-2}-\ldots-\lambda_{q} e_{t-q}
$$

şeklinde gösterilir.

Bileşik ya da entegrasyonu yapılmış modelse (ARMA) şöyle ifade edilir:

$Y=\delta_{1} Y_{t-1}+\delta_{2} Y_{t-2}+\ldots .+\delta_{p} Y_{t-p}+e_{t}-\lambda_{1} e_{t-1}-\lambda_{2} e_{t-2}-\ldots . \lambda_{q} e_{t-q}$

Yukarıdaki eşitliklerde;

Y: Bağımlı (açıklanan) değişkendir.

$\delta_{1}, \delta_{2}, \delta_{\mathrm{p}}=$ Kısmi otokorelasyonu gösteren katsayılardır. Otokorelasyon katsayıS1 anlamlı olduğu takdirde AR modelinin derecesini yani p'yi belirlerler.

$\lambda_{1}, \lambda_{2}, \lambda_{\mathrm{q}}=$ Kısmi otokorelasyonu gösteren katsay1lardır. Otokorelasyon katsayıs1 anlamlı olduğu takdirde MA modelinin derecesini yani q'yu belirlerler.

$\mathrm{e}_{\mathrm{t}}=$ Modelin standart hata terimidir.

Box-Jenkins'e göre AR modelinin derecesi $p$ ve MA modelinin derecesi q birlikte ARMA $(\mathrm{p}, \mathrm{q})$ modelini oluştururlar.

Diğer taraftan zaman serilerinin çoğunluğu durağan değildir. Box-Jenkins (ARIMA) modelinin kullanılabilmesi için serilerin ya durağan olması ya da farkları alındığında durağanlaşması gereklidir. Durağan olmayan ve d. dereceden bütünleşik olan bir zaman serisi d kez farkı alındığında durağanlaşır. Box-Jenkins'e göre ARMA (p,q) modeline serininin bütünleşme derecesi olan (d) eklendiğinde nihai modelimiz olan "Bileşik (Bütünleşik) Otoregresif Hareketli Ortalama" diğer bir gösterimle ARIMA (p,d,q) elde edilir. Bütünleşme derecesinin belirlenmesi için ön bilgi olarak otokorelasyonu gösteren korelograma bakılabilir veya nihai karar için birim kök testleriyle serinin durağanlık düzeyi araştırılır (Hamzaçebi ve Kutay, 2004, s. 2-3).

\section{Uygulama ve Bulgular}

Çalışmanın bu bölümünde öncelikle Türkiye'de Dış Borç Stoku (DEBT), Ekonomik Büyüme (GDP) ve İhracat (EX) değişkenlerinin durağanlık seviyelerini tespit etmek için standart birim kök testleri uygulanacaktır. Daha sonra her bir seri için en uygun ARIMA modeli belirlenip gelecek beş yıl değerleri tahminlenecektir. Son olarak da bulunan tahmin değerlerinin oranlanmasıyla Türkiye'de dış borçların sürdürülebilir olup olmadığı konusunda çıkarımda bulunmaya çalış1lacaktır.

\subsection{Birim Kök Testleri}

Durağan olmayan zaman serilerinde ortaya çıkması muhtemel olan sahte regresyon sorununun saptanabilmesi için literatürde uzunca bir süredir ön test olarak birim kök testleri kullanılmaktadır. Bu alandaki en yaygın kullanım ADF (Düzeltilmiş Dickey Fuller) testidir. Bununla birlikte birçok çalışmada PP (Philips-Perron) testi de ADF'yi destekleyici birim kök testi olarak kullanılmaktadır.

Durağanlığın sınanması yani bütünleşme derecesinin belirlenebilmesi için serilere (DEBT, GDP ve EX) ait birim kök test sonuçları Tablo 7'de sunulmuştur. 
Tablo 7. Serilerin durağanlık sinamaları***,***

\begin{tabular}{|c|c|c|c|c|c|c|c|c|c|}
\hline & \multirow[t]{2}{*}{$\begin{array}{c}\text { Model } \\
\text { Özelliği }\end{array}$} & \multicolumn{2}{|c|}{$\mathrm{ADF}$} & \multicolumn{2}{|c|}{$\mathrm{PP}$} & \multicolumn{3}{|c|}{ Kritik Değerler } & \multirow[t]{2}{*}{ Sonuç } \\
\hline & & Seviye & 1. Fark & Seviye & 1. Fark & $\% 1$ & $\% 5$ & $\% 10$ & \\
\hline DEBT & $\begin{array}{c}\text { Trendli } \\
\text { ve } \\
\text { Sabitli }\end{array}$ & $\begin{array}{c}-1,82 \\
{[0,6639]}\end{array}$ & $\begin{array}{c}-3,91 \\
{[0,0266]}\end{array}$ & $\begin{array}{c}-1,83 \\
{[0,6577]}\end{array}$ & $\begin{array}{c}-3,77 \\
{[0,0352]}\end{array}$ & $-4,35$ & $-3,59$ & $-3,23$ & I (1) \\
\hline GDP & $\begin{array}{c}\text { Trendli } \\
\text { ve } \\
\text { Sabitli }\end{array}$ & $\begin{array}{c}-2,06 \\
{[0,5425]}\end{array}$ & $\begin{array}{c}-4,70 \\
{[0,0048]}\end{array}$ & $\begin{array}{c}-2,06 \\
{[0,5425]}\end{array}$ & $\begin{array}{c}-4,70 \\
{[0,0048]}\end{array}$ & $-4,35$ & $-3,59$ & $-3,23$ & $\mathrm{I}(1)$ \\
\hline EX & $\begin{array}{c}\text { Trendli } \\
\text { ve } \\
\text { Sabitli }\end{array}$ & $\begin{array}{c}-2,07 \\
{[0,5328]}\end{array}$ & $\begin{array}{c}-4,47 \\
{[0,0080]}\end{array}$ & $\begin{array}{c}-2,13 \\
{[0,5062]}\end{array}$ & $\begin{array}{c}-4,44 \\
{[0,0086]}\end{array}$ & $-4,35$ & $-3,59$ & $-3,23$ & $\mathrm{I}(1)$ \\
\hline
\end{tabular}

*Kritik değerler Mackinnon (1996)'dan alınmıştır. **Köşeli parantez içindeki değerler olasılık (probability) değerleridir. *** Maksimun gecikme sayısı 6 olarak belirlenmiş ve testler Schwarz Bilgi Kriterine göre yapılmıştır.

Tablo 7'ye göre ADF ve PP testleriyle, Dış Borç Stoku (DEBT) serisinin düzey değerinde hesaplanan değer kritik değerden küçük olduğu ve olasıl1k değeri 0,05 'ten büyük olduğu için serinin durağan olmadığını öne süren $\mathrm{H}_{0}$ hipotezi reddedilememekte yani söz konusu serinin birim kök içerdiği görülmektedir. Yine aynı serinin birinci farkı alındığındaysa hesaplanan değer kritik değerden büyük olduğu ve olasılık değeri 0,05 'ten küçük olduğu için seri durağan değildir anlamına gelen $\mathrm{H}_{0}$ hipotezi reddedilmekte yani serinin birinci farkında durağan olduğu sonucuna varılmaktadır. Buna göre DEBT serisi birinci farkında durağandır diğer bir deyişle I (1)'dir.

Benzer şekilde Gayri Safi Yurt İçi Hâsıla (GDP) serisi de birinci farkında durağan yani I (1)'dir. Yine aynı koşulların geçerli olduğu İhracat (EX) serisi de I (1)'dir. Yani birinci farkında durağandır.

Serilerin bütünleşme dereceleri tespit edildikten sonra ARIMA modelinin tahminine geçilebilir.

\subsection{ARIMA Modeli Tahmin Sonuçları}

Çalışmanın bu kısmında Türkiye'nin 1990-2016 yıllık verilerini içeren Dış Borç Stoku (DEBT), Ekonomik Büyüme (GDP) ve İhracat (EX) serilerinin geçmiş değerlerinden yola çıkılarak (9 yıl, 2017-2025) bir öngörü yapılacaktır. Bunun için Bütünleşik Otoregresif Hareketli Ortalama (ARIMA) metodu kullanılacaktır. Serilerin 1990-2016 dönemi yıllık gözlenen değerleri Tablo 8'de sunulmuştur. 
Tablo 8. Serilerin gözlenen değerleri (Milyon ABD doları)

\begin{tabular}{|c|c|c|c|}
\hline & $\begin{array}{c}\text { TÜRKIYE BRÜT } \\
\text { DIŞ BORÇ } \\
\text { STOKU (DEBT) }\end{array}$ & $\begin{array}{c}\text { EKONOMIK } \\
\text { BÜYÜME } \\
\text { (GDP) }\end{array}$ & $\begin{array}{l}\text { İHRACAT } \\
\quad(\mathbf{E X})\end{array}$ \\
\hline 1990 & 52.381 & 150.676 & 12.959 \\
\hline 1991 & 53.623 & 150.028 & 13.595 \\
\hline 1992 & 58.595 & 158.459 & 14.716 \\
\hline 1993 & 70.512 & 180.170 & 15.343 \\
\hline 1994 & 68.705 & 130.690 & 18.106 \\
\hline 1995 & 75.948 & 169.486 & 21.599 \\
\hline 1996 & 79.299 & 181.476 & 23.245 \\
\hline 1997 & 84.356 & 189.835 & 26.260 \\
\hline 1998 & 96.351 & 275.769 & 26.881 \\
\hline 1999 & 103.123 & 255.884 & 26.587 \\
\hline 2000 & 118.602 & 272.979 & 27.775 \\
\hline 2001 & 113.592 & 200.252 & 31.334 \\
\hline 2002 & 129.601 & 238.428 & 36.059 \\
\hline 2003 & 144.172 & 311.823 & 47.253 \\
\hline 2004 & 161.154 & 404.787 & 63.167 \\
\hline 2005 & 170.757 & 501.416 & 73.476 \\
\hline 2006 & 208.002 & 552.487 & 85.535 \\
\hline 2007 & 249.926 & 675.770 & 107.272 \\
\hline 2008 & 280.774 & 764.336 & 132.027 \\
\hline 2009 & 268.698 & 644.640 & 102.143 \\
\hline 2010 & 291.645 & 771.877 & 113.883 \\
\hline 2011 & 303.678 & 832.546 & 134.907 \\
\hline 2012 & 339.494 & 873.982 & 152.462 \\
\hline 2013 & 389.684 & 950.595 & 151.803 \\
\hline 2014 & 401.728 & 934.168 & 157.610 \\
\hline 2015 & 395.862 & 859.794 & 143.839 \\
\hline 2016 & 404.890 & 863.712 & 142.530 \\
\hline
\end{tabular}

Kaynak: Hazine Müsteşarlığı, Dünya Bankası, Dünya Ticaret Örgütü

Değişkenlere ait en uygun ARIMA modelleri Akaike Bilgi Kriteriyle (AIC) tespit edilmiştir. Dış Borçlar (DEBT) serisi için 20 farklı deneme içersinden seçilen uygun model $\operatorname{ARIMA}(0,1,0)$ 'dır. Ekonomik Büyüme (GDP) için seçilen en uygun modelse ARIMA $(0,1,0)$ 'dır. Benzer şekilde İhracat $(E X)$ modeli için seçilen en uygun model de ARIMA $(0,1,0)$ olarak tespit edilmiştir. 
2017-2025 için tahmin edilen değerler Tablo 9'da sunulmuştur.

Tablo 9. ARIMA modeliyle tahmini yapılan değerler (Milyon ABD doları)

\begin{tabular}{cccc}
\hline & $\begin{array}{c}\text { TAHMIN EDILEN } \\
\text { TÜRKIYE BRÜT DIŞ } \\
\text { BORÇ STOKU }\end{array}$ & $\begin{array}{c}\text { TAHMIN EDILEN } \\
\text { (DEBT) }\end{array}$ & $\begin{array}{c}\text { TAHMIN EDİLEN } \\
\text { IHRACAT } \\
(\text { EX) }\end{array}$ \\
\hline 2017 & 438.023 & 923.708 & 147.513 \\
2018 & 473.867 & 987.873 & 152.496 \\
2019 & 512.645 & 1.056 .496 & 157.480 \\
2020 & 554.597 & 1.129 .884 & 162.463 \\
2021 & 599.981 & 1.208 .371 & 167.446 \\
2022 & 649.079 & 1.298 .884 & 172.430 \\
2023 & 702.195 & 1.292 .310 & 177.413 \\
2024 & 759.657 & 1.478 .084 & 182.397 \\
2025 & 821.822 & 1.580 .759 & 187.380 \\
\hline
\end{tabular}

Tablo 9'a göre 2016 yılında 404.890 milyon dolar olan Türkiye'nin dış borcunun 2017 yılında yaklaşık \%8 artarak 438.023 milyon dolara çıkması tahmin edilmektedir. Yine aynı dönemde GSYİH'nin 863.712 milyon dolardan \% 7 artarak 923.873 milyon dolara çıkmas1 beklenmektedir. İhracatınsa 2016 y1lında 142.530 milyon dolardan yaklaşı \% 3 artışla 2017 yılında 147.513 milyon dolara yükselmesinin beklendiği görülmektedir. Doğrusal bir modelle oluşturulan bu sonuçlara göre Türkiye'de dış borç artışının genel olarak ekonomik büyüme artışının ve ihracat artışının üzerinde olacağı tahmin edilmektedir.

Tablo 10'da tahmin edilen değerlerin oranlanması görülmektedir. Çalışmanın nihai hedefinin risk faktörü açısından dış borçların sürdürülebilir olup olmadığını belirlemek olduğundan ve cari değer probleminin aşılması açısından oran analizi gereklidir. Nitekim bu sayede Türkiye'de 2017-2025 döneminde dış borçların sürdürülebilir olup olmadığı hakkında fikir sahibi olunabilir.

Tablo 10. Tahmin edilen değerlerin oranlanması

\begin{tabular}{ccc}
\hline & $\begin{array}{c}\text { DIŞ BORÇ } \\
\text { STOKU/GSYIH }\end{array}$ & $\begin{array}{c}\text { DIŞ BORÇ STOKU/ } \\
\text { IHRACAT } \\
(\%)\end{array}$ \\
\hline 2017 & 47,4 & 296,9 \\
2018 & 48,0 & 310,7 \\
2019 & 48,5 & 325,5 \\
2020 & 49,1 & 341,4 \\
2021 & 49,7 & 358,3 \\
2022 & 50,0 & 376,4 \\
2023 & 54,3 & 395,8 \\
2024 & 51,4 & 416,5 \\
2025 & 52,0 & 438,6 \\
\hline
\end{tabular}

Tablo 10'a göre Türkiye'de “Dış Borç Stoku/GSYİH” oranının 2017 yılında \% 47,4 olması beklenirken, 2025 yılında bu oranın \% 52'ye çıkacağı tahmin edilmektedir. Bununla birlikte Türkiye'de dış borç artış hızının halen ekonomik büyüme hızından yüksek olması nedeniyle söz konusu oranın giderek kötüleştiği söylenebilir. Ayrıca çalışmanın ikinci bölümünde yapılan analizlere göre dış borç stoku artış hızının ekonomik büyüme hızından yüksek olmakla beraber bu yüzdelik oranın azalış eğiliminde olduğu da dikkatlerden kaçmamalıdır. 
Diğer taraftan Dünya Bankası'na göre "Dış Borç Stoku/GSYİH” sınır oranı \%50'dir. Bu değer üzerindeki oranlar mali açıdan yüksek risk grubunu ifade etmektedir. Maastricht Kriterleri'ne göreyse Avrupa Birliği üyeleri ve aday ülkeler için kabul edilebilir Kamu Borcu/GSYİH oran $1 \% 60$ ’tır. Buna ek olarak ikinci bölümde de değinildiği üzere Türkiye BRICS ülkeleri arasında söz konusu oran açısından en kötü performansa sahip olan ülkedir.

Bununla birlikte "Dış Borç Stoku/İhracat” oranına bakıldığında Dünya Bankası’nın \% 275 olan eşik değerinin çok fazla üzerinde bulunulduğu görülmektedir. Ve bu oran giderek daha da kötüleşmektedir. $\mathrm{Bu}$ gösterge Türkiye'nin ihracatının dış borçlarını döviz olarak karşılayabilme yeteneğini ölçmesi bakımından önemlidir ve ciddi şekilde olumsuz sinyaller vermektedir. Fakat bu noktada özellikle ihracat rakamlarındaki yüksek oynaklık nedeniyle tahminlerdeki hata payının yüksek olabileceği beklenildiği için bu sonucun güvenilirliği kuşkuludur. Nitekim 2017 yılında Türkiye resmi rakamlara göre 157,1 milyar dolar ihracat gerçekleştirmiş̧ir. Bu rakam çalışmadaki 147,5 milyar dolar tahminiyle önemli ölçüde farklıdır.

\section{Sonuç}

Küreselleşme sonucunda uluslararası siyasi ve ekonomik sınırlar hızla kalkmakta ve devletler arasında sermayenin akışı hızlanmaktadır. Özellikle gelişmiş ülkelerden az gelişmiş ya da gelişmekte olan ülkelere doğru yapılan bu fon akışlarının en önemli bileşenlerinden biri de dış borçlanmadır. Dış borçlanma çağdaş dünyada kalkınma ya da ekonomik büyüme için belki de olmazsa olmazlardandır. Fakat dış borç alan ülkelerin söz konusu borçların anaparasını ve faizini geri ödeme hususunda uzun vadede olumsuz etkilendiği de bir diğer gerçekliktir.

Bilindiği üzere Türkiye uzun yıllar görece istikrarsız bir ekonomik yapıya sahip olmuştur. Popülist ve günü kurtarmaya yönelik politikalar dış borç yönetiminde de etkinliğin ve verimliliğin yitirilmesine yol açmıştır. Nitekim aslında her ülke için dış borç yönetimi siyasi amaçların üzerinde ulusal bir politika anlayışı çerçevesinde yürütülmelidir. Dahası ne yazık ki ülkeler ailesinde Türkiye gerek ekonomik gerek siyasi en riskli ülkelerden biri olduğu için ülkemizde geçmişten günümüze etkin bir diş borç yönetimini gerçekleştirmek de kuşkusuz ki oldukça zor olmuştur. Yine de bugün gelinen noktada Türkiye'de dış borç yönetiminde olağanüstü bir olumsuzluğun olmadığı fakat diğer birçok konuda olduğu gibi yüksek risk gerçeğinin karşımızda olduğu söylenebilir.

Her ne kadar Türkiye'de diş borçların sürdürülebilirliği konusunda net bir sonuca ulaşmak büyük ölçüde değer yargılarına bağlı olsa da bu çalışmada yapılan analizlere ve karşılaştırmalara göre yüksek dereceli olumsuz bir durumun olmadığ ileri sürülebilir. Bununla birlikte makroekonomik performans açısından Türkiye bugün kırılgan başka bir ifadeyle hassas bir yapıya sahip olduğu için dış borç yönetimindeki ciddiyet mutlaka korunmalıdır. Yine de bu çalışmada oluşan kanaati literatürdeki bulgularla ilişkilendirmek gerçekçidir. Nitekim bu çalışmanın sonucu Azgün'ün (2005) bulguladığı sonucu desteklemektedir. Fakat Yavuz ve Çiçek (2006) ve Yılancı'nın (2008) sonucuyla çelişmektedir. Bu farklılı̆̆ın değerlendirmeye esas alınan kriterlerin farklı olmasından, farklı dönemlerin incelenmesinden ve belki de en önemlisi söz konusu yazarların değer yargılarının yani perspektiflerinin farklı olmasından kaynaklandığı söylenebilir.

Nihayetinde bu çalışmaya göre Türkiye'de dış borçlar sürdürülebilirdir. Fakat analiz sonuçlarına ve uluslararası kriterlere bakılırsa Türkiye'nin dış borç yönetiminde eşik noktasında olduğu diğer bir deyişle dış borç yönetiminde temkinli davranması gerektiği açıktır. Çalışmanın literatür taraması bölümünden de görüldüğü üzere dış borçların ekonomik büyümeyi negatif etkilemesi ve sürdürülebilirliğin sağlanması açısından konunun Türkiye açısından hassasiyetle değerlendirilmesi zaruridir. Bu noktada dış borç stokunun gelecek nesiller üzerinde ciddi bir ekonomik yük oluşturması da hassasiyet gösterilmesi gereken bir diğer husustur. 


\section{Kaynakça}

Afonso, A. ve Alves, J. (2014). The role of government debt in economic growth. ISEG-UTL Economics Department Working Paper, 16,1-45.

Akan, Y. ve Kanca, O. C. (2015). Türkiye'de diş borçlanma, büyüme ve enflasyon ilişkisi: var yaklaşımı (1980-2013). Hacettepe Üniversitesi Íktisadi ve İdari Bilimler Fakültesi Dergisi, $33(3), 1-22$.

Akinwunmi, A. A. ve Adekoya, R. B. (2018). Assessment of the 1mpact of external borrowing on the economic growth of the developing countries-Nigerian experience, Asian Business Research, 3(1), 29-40.

Aktan, Ç. C. (2004). Yeni iktisat okulları. Ankara: Seçkin Yayıncılık San. ve Tic. A.Ş.

Arslan, M. (2014). The Role of external debt on economic growth: evidence from Pakistan economy. Journal of Economics and Sustainable Development, 5(24), 140-147.

Ataç, B. (2006). Maliye politikası. Eskişehir: ETAM A.Ş.

Azgün, S. (2005). Dış borç sürdürülebilirligi: zamanlararası bütçe kısıtı testleri. Sosyal Bilimler Dergisi, (2),57-68.

Bal, D. P. ve Rath, B. N. (2014). public debt and economic growth in India: a reassessment. Economic Analysis and Policy, (44), 292-300.

Bilginoğlu, M. A. ve Aysu, A. (2008). Dış borçların ekonomik büyüme üzerindeki etkisi: Türkiye örneği. Erciyes Üniversitesi İktisadi ve İdari Bilimler Fakültesi Dergisi, (31), 1-23.

Bittencourt, M. (2015). determinants of government and external debt: evidence from the young democracies of south America. Emerging Markets Finance \& Trade, (51), 463-472.

Box, G. E. P. ve Jenkins, G. (1976), Time series analysis: forecasting and control. 2nd Edition, San Francisco: Holden-Day.

Chirwa, T. G. ve Odhiambo, N. M. (2018). The determinants of public debt in the euro area: a panel ARDL approach. Unisa Economic Research Working Paper Series, 1-34.

Çoban, A., Çoban, O., Baysal Kurt, D. ve Abdou Baoua, M. M. (2016). Nijer'de dış borç ve ekonomik büyüme ilişkisi, Selçuk Üniversitesi Sosyal Bilimler Meslek Yüksekokulu Dergisi, 19(2), 165-182.

Çögürcü, İ. ve Çoban, O. (2011). Dış borç ekonomik büyüme ilişkisi: Türkiye örneği (19802009). KMÜ Sosyal ve Ekonomik Araştırmalar Dergisi, 13(21), 133-149.

Çukurçayır, S. (2014). Türkiye ekonomisinde dış borçların sürdürülebilirliği: eşbütünleşme analizi. Sosyoekonomi, (2), 9-31.

Dünya Bankası (2019). https://data.worldbank.org/ (Erişim tarihi: 09.10.2019).

Dünya Ticaret Örgütü (2019). http://stat.wto.org/ (Erişim tarihi: 09.10.2019).

Gürdal, T. ve Yavuz, H. (2015). Türkiye'de dış borçlanma-ekonomik büyüme ilişkisi: 1990-2013 dönemi. Maliye Dergisi, (168), 154-169.

Hamzaçebi, C. ve Kutay, F. (2004). Yapay sinir ağları ile Türkiye elektrik enerjisi tüketiminin 2010 y1lına kadar tahmini. Gazi Üniversitesi Mühendislik-Mimarlık Fakültesi Dergisi, (19), 227-233.

Hazine Müsteşarlığı (2019). https://www.hmb.gov.tr/ (Erişim tarihi: 09.10.2019). 
Kutlu, S. ve Yurttagüler, İ. M. (2016). türkiye'de dış borç ve ekonomik büyüme ilişkisi: 19982014 dönemi icin bir nedensellik analizi. Marmara Üniversitesi İktisadi ve İdari Bilimler Dergisi, 38(1), 229-248.

Lee, S. P. ve Ng, Y. L. (2015). Public debt and economic growth in Malaysia. Asian Economic and Financial Review, 5(1), 119-126.

Mackinnon, J. G. (1996). Numerical distribution functions for unit root and cointegration tests. Journal of Applied Econometrics, (11), 601-618.

Malik, S., Hayat, M. K. ve Hayat, M. U. (2010). External debt and economic growth: empirical evidence from Pakistan. International Research Journal of Finance and Economics, (44), 8897.

Mencinger, J., Aristovnik, A. ve Verbic, M. (2014). the 1mpact of growing public debt on economic growth in the European Union. Amfiteatru Economic Journal, 16(35), 403-414.

Muhanji, S. ve Ojah, K. (2011). Management and sustainability of external debt: a focus on the emerging economies of Africa. Review of Development Finance, (1), 184-206.

Mutluer, K., Öner, E. ve Kesik, A. (2007). Teoride ve uygulamada kamu maliyesi. İstanbul: İstanbul Bilgi Üniversitesi Yayınları.

Nawaz, M., Qureshi, M. ve Awan, N. W. (2012). does external debt causes economic growth: a case study of Pakistan. The Romanian Economic Journal, 15(43), 131-144.

Öztürk, N. (2012). Maliye politikası. Bursa: Ekin Yayınevi.

Peker, O. ve Bölükbaş, M. (2013). Türkiye'de dış borçlanmanın belirleyicileri: ekonometrik bir analiz. Atatürk Üniversitesi İktisadi ve İdari Bilimler Dergisi, 27(2), 289-302.

Pinar, A. (2014). Maliye politikası teori ve uygulama. Ankara: Turhan Kitapevi.

Schclarek, A. (2004). Debt and economic growth in developing and industrial countries, Lund University, Department of Economics Working Papers, (34), 1-39.

Siddique, A., Selvanathan, E. A. ve Selvanathan, S. (2016). The impact of external debt on growth: evidence from highly indebted poor countries. Journal of Policy Modeling, (38), 874894.

Tülümce, S. Y. ve Yavuz, E. (2017). Türkiye'de borçlanma ve ekonomik büyüme arasındaki ilişki. Uluslararası Yönetim İktisat ve Iş̧letme Dergisi, ICMEB17 Özel Sayısı, 1034-1048.

Ulusoy, A. (2007). Maliye politikası. Trabzon: Üçyol Kitabevi.

Umaru, A., Hamidu, A. A. ve Musa, S. (2013). External debt and domestic debt 1mpact on the growth of the Nigerian economy. International Journal Educational Research, 1(2), 70-85.

Uysal, D., Özer, H. ve Mucuk, M. (2009). Dış borçlanma ve ekonomik büyüme ilişkisi: Türkiye örneği (1965-2007). Atatürk Üniversitesi İktisadi ve İdari Bilimler Dergisi, 23(4), 161-178.

Westphal, C. C. ve Rother, P. (2012). The 1mpact of high government debt on economic growth and its channels: an empirical investigation for the euro area. European Economic Review,56(7), 1392-1405.

Yavuz, A. (2009). Başlangıcından bugüne Türkiye'nin borçlanma serüveni: durum ve beklentiler. SDÜ Fen Edebiyat Fakültesi Sosyal Bilimler Dergisi, (20), 203-226.

Yavuz, A. ve Çiçek, H. G. (2006). Türkiye'nin 1994-2005 yılları arasında dış borçların dış borç rasyo analizleri ile değerlendirilmesi. Süleyman Demirel Üniversitesi İktisadi ve İdari Bilimler Fakültesi Dergisi, 11(1), 97-120. 
Yılanc1, V. ve Özcan, B. (2008). External debt sustainability of Turkey: a nonlinear approach. International Research Journal of Finance and Economics, (20), 91-98.

\section{ETIKK ve BİLIMSEL İLKELER SORUMLULUK BEYANI}

$\mathrm{Bu}$ çalışmanın tüm hazırlanma süreçlerinde etik kurallara ve bilimsel atıf gösterme ilkelerine riayet edildiğini yazar(lar) beyan eder. Aksi bir durumun tespiti halinde Afyon Kocatepe Üniversitesi Sosyal Bilimler Dergisi'nin hiçbir sorumluluğu olmayıp, tüm sorumluluk makale yazarlarına aittir. 